\title{
EVALUATION OF BIODEGRADABILITY OF WASTE BEFORE AND AFTER AEROBIC TREATMENT
}

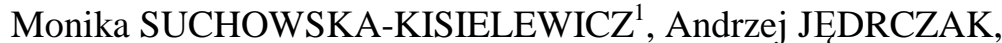 \\ Zofia SADECKA
}

University of Zielona Gora, Institute of Environmental Engineering, Poland

\begin{abstract}
An important advantage of use of an aerobic biostabilization of waste prior to its disposal is that it intensifies the decomposition of the organic fraction of waste into the form which is easily assimilable for methanogenic microorganisms involved in anaerobic decomposition of waste in the landfill. In this article it is presented the influence of aerobic pre-treatment of waste as well as leachate recirculation on susceptibility to biodegradation of waste in anaerobic laboratory reactors. The research has shown that in the reactor with aerobically treated waste stabilized with recilculation conversion of the organic carbon into the methane is about $45 \%$ higher than in the reactor with untreated waste stabilized without recirculation.
\end{abstract}

Keywords: aerobic pre-treatment of waste; biodegradability of waste landfills; biogas production; municipal solid waste

\section{INTRODUCTION}

Content of organic substances in wastes has a decisive influence on the amount of pollutants and on the duration of their emissions from landfills [17]. In Poland and other European countries the European Union Council imposed directive 1999/31/EC on reducing the amount of easily-biodegradable organic waste deposited at landfills [3]. In these countries it has been scheduled to reduce the amount of landfilled organic waste by: $25 \%$ by $2010,50 \%$ by 2013

\footnotetext{
${ }^{1}$ University of Zielona Gora, Institute of Environmental Engineering, Licealna 9, 65-417 Zielona Gora, Poland, corresponding e-mail: M.SuchowskaKisielewicz@iis.uz.zgora.pl, tel. $+48683282560$
} 
and $65 \%$ by 2020 , in comparison with the quantity of waste produced in 1995 $[3,5]$. The reduction of organic fraction of municipal solid waste (MSW) directed into the landfill can be achieved in the following ways [17]:

- Separated collection of organic fractions of MSW to produce compost;

- Thermal treatment of MSW to produce energy;

- Pretreated mechanical-biological treatment (MBT) to reduce its reactivity and mass before being disposed into a landfill [5].

According to the 2010 National Waste Management Plan adopted in Poland the mechanical-biological treatment of MSW is recommended as a method appropriate for agglomerations with upto 300000 residents.

The process of the MBT consists of a mechanical waste sorting combined with an installation for the biological stabilisation of the biodegradable fraction of waste. The mechanical waste treatment stage can be placed either at the beginning of the MBT process (biostabilisation), or after the biological process (biodrying). In order to reduce the amount of biodegradable waste aerobic or anaerobic decomposition is applied in biostabilisation technologies. The stabilized waste obtained in the MBT process is used mainly for landfilling, but it can be also used as fertiliser for non-agricultural land and for the reclamation of land for construction, or it can be burnt in municipal waste incineration plants $[1,8,6]$. The main purpose of this biostabilization technology is to achieve the highest possible degree of stabilisation of organic waste, so that emission of pollutants from stabilised waste deposited at landfills is as low as possible. Additionally, MBT systems allow us to increase reclamation of materials for recycling and to reduce the quantity of deposited waste $[13,9,4,17]$.

In developing countries the recommended method of biological waste stabilisation before landfilling is aerobic decomposition. This requires less investment and operating expenditures in comparison to the anaerobic processes [10]. An important advantage of using aerobic biostabilization for waste prior to its disposal is that it intensifies decomposition of the recalcitrant organic fraction of waste into a form easily assimilable for methanogenic microorganisms involved in anaerobic decomposition of waste in a landfill $[2,7$, $14,15,19]$.

The length of the aerobic pretreatment of waste influences on the degree of biological stability of waste. For example in Germany and Austria the biological treatment of waste is conducted during 2-6 months to obtain high biological stability of waste prior to its disposal in a landfill [17]. In Poland the process of biostabilization is carried out for 2-5 weeks of intensive aeration in order to obtain a product with a medium biological stability level. The research presented by other authors indicated that the process conducted longer than 4 weeks do not increase the degree of stabilization significantly [17]. 
Pre-treatment of waste prior to its desposal into a landfill supports sustainable landfilling by minimizing landfill emissions. Moreover, the aftercare requirement can be significantly reduced.

The main advantages of mechanical-biological pretreat of waste prior to landfilling are [21]:

- landfill area reduction up to $40 \%$, thus conserving land resources and reducing the cost of landfilling,

- reduction of biodegradability of waste, thereby reducing methane and leachate production on landfills.

- reduction of potential hazardous waste contaminants in the waste stream, such as batteries, solvents, paints, fluorescent light bulbs,

- increase of recycling, reusing and recovering of waste materials.

In order to accelerate the wastes decomposition process, to reduce time of pollutant emission and to treat leachate in landfills recirculation of leachate can be carried out [23].

Recirculation increases the moisture content of waste, lowers the concentration of potential methanogenesis inhibitors [11] and supplies the nutrients and enzymes necessary for microbial growth [20].

Besides accelerating decomposition of organic components of the waste the benefits of leachate recirculation includes an increase in methane production [16] and the removal of some of the pollutants presented in the recirculated leachate.

The leachate produced in landfills is due to the following factors: rainwater percolation, leaching of solid waste moisture content, water production with biochemical process, and ground water entering into the waste mass during operating a landfill. A promising method in leachate management is treating the landfill as a bioreactor in which recilculation of leachate allows us to maintain appropriate monsiure condition in order to enhance the level of degradation of the biodegradable organic fractions of the waste. Commonly practiced leachate treatment methods, such as flocculation/precipitation, activated carbon adsorption, membrane filtration, and chemical oxidation are complicated, expensive and generally require multiple processes. Therefore, the identification and application of effective in-situ treatment technologies of leachate is urgently needed in developing countries [22].

In the article the influence of aerobic pre-treatment of waste by 5 weeks on susceptibility to biodegradation of waste in anaerobic laboratory reactors with and without leachate recirculation are presented.

The rate of conversion of the biodegradable carbon to methane was assumed as an indication of biodegradability [12]. 


$$
W_{C H_{4}}=\frac{\mathrm{CH}_{4} \cdot \frac{12(\mathrm{mg} / \mathrm{mmol})}{25,4(\mathrm{ml} / \mathrm{mmol})}}{C_{B I O}} \cdot 100 \%
$$

where:

$\mathrm{CH}_{4}$ - methane production, (ml);

$\mathrm{C}_{\mathrm{BIO}}$ - biodegradable carbon contained in the waste, $(\mathrm{mg})$.

\section{EXPERIMENT}

\subsection{Test material}

In order to carry out the tests both biologically untreated and treated municipal solid waste was used (Table 1). This waste was taken from high-rise buildings with central heating in Zielona Góra.

Biological waste treatment was conducted using the works of the Zielona Góra Municipal Waste Composting Plant. The process line of the Composting Plant consists of four aerobic, open reinforced concrete chambers among which waste is transferred every 7-10 days. The total waste stabilisation time is about 5 weeks. Waste is aerated by sucking out the gasses from the bottoms of the ferroconcrete chambers.

Samples for determination of the composition of the examined municipal solid waste were taken from randomly selected vehicles delivering waste to the composting plant's bunker. Samples of biologically treated solid waste (BSW) were taken at random from the chosen batches of composted waste.

The properties of the examined waste were determined by analysing $10 \mathrm{MSW}$ and $10 \mathrm{BSW}$ samples. The group composition of the untreated and treated waste was determined in the $>10 \mathrm{~mm}$ fraction by separating the following morphological constituents: kitchen and garden waste, paper and cardboard, glass, plastics, textiles, multi-material packaging, wood, metals and mineral wastes. The group composition of the fraction was expressed as a percentage of a constituent in the general mass of the waste, in \% (v/v).

Chemical analysis was conducted on samples of waste without large-size constituents and metals. The scope of the analysis included the following parameters: moisture, volatile substances (loss on ignition at $550^{\circ} \mathrm{C}$ ), organic carbon (Table 1). All determinations were conducted in accordance with the procedures of Standard Methods (APHA, 1995) and Polish Standards. 


\subsection{Testing stations}

The laboratory tests were conducted in four reactors made from PVC pipes 0.15 $\mathrm{m}$ in diameter and $1.30 \mathrm{~m}$ in height. In the bottom of each reactor, a stub (a pipe with a valve) was installed for draining the leachate, and in the lid a stub for discharging biogas, and a stub for dosing water, in order to simulate precipitation.

The collected leachate was stored in a tank with a capacity of $20 \mathrm{dm}^{3}$. The gas stub in the reactor's lid was connected by $10 \mathrm{~mm}$ flexible pipelines to gas burettes (cylinders with an internal diameter of $85 \mathrm{~mm}$ with graduation). The other stub in the reactor's lid was connected to a tank with water simulating precipitation.

Before filling the reactors with waste, a 0.15 m layer of graver to simulating the filter layer in landfill was placed on their bottoms and thermocouples were installed. Into each reactor was poured $10 \mathrm{~kg}$ of waste crushed to grain size $<40$ $\mathrm{mm}$ and thoroughly mixed. After filling the reactors with waste and closing them hermetically, dosage of water began for each of them, at the amount of $1 \mathrm{dm}^{3} / \mathrm{d}$, in order to saturate the waste with water.

As soon as the first quantities of leachate have appeared (after 7 days), the daily dosage of tap water began for each of the reactors, in the amount simulating real precipitate, determined based on monthly reports of the Zielona Góra Institute of Meteorology.

For one reactor filled with untreated waste and one reactor filled with treated waste were connected by pipelines to the recirculation of leachate. These reactors were called: SR and PR, respectivly. The remaining two reactors were called: reactor $S$ - filled with untreated waste and $\mathrm{P}$ - filled with treated waste. Leachate was recirculated once a week in the amount of $1 \mathrm{dm}^{3}$. The temperature in the room with the reactors ranged between 20 and $25^{\circ} \mathrm{C}$.

\subsection{Process control}

The process control involved the testing of the quantity and quality of leachate and biogas. Quantitative tests were conducted every day and qualitative ones once a week. The study was conducted for 52 weeks.

The initial content of organic carbon in biodegradable waste stabilized under anaerobic conditions without recirculation determined based on equation (2.1) [18]:

$$
C_{\text {BIO }}=C_{\text {org }_{i}} f_{\text {BIO }}(1-w) p_{i}
$$

where:

$C_{B I O}-$ is the biodegradable mass of carbon in the waste, 
$\begin{array}{ll}C_{{ }_{{ }_{\text {O }}}} & - \text { is the mass of organic carbon in the i-th component of the waste, } \\ f_{B I O_{i}} & - \text { is the contribution of biodegradable fraction in organic carbon, } \\ w_{i} & - \text { is the moisture of the i-th waste component, } \\ p_{i} & - \text { is the weight participation of the i-th component. }\end{array}$

As biodegradable wastes were adopted the kitchen and vegetable waste.

The content of carbon in untreated and aerobically treated waste stabilized in anaerobic reactors with recirculation was determined by the equations (2.2), (2.3), (2.4):

$$
C_{B I O_{R}}=C_{B I O}+\left(C_{W P R_{B Z T_{5}}}-C_{U S_{B Z T_{5}}}\right)
$$

where:

$C_{B I O_{R}} \quad-$ is the mass of biodegradable carbon in waste stabilized in reactors with recirculation of leachate,

$C_{B I O} \quad-$ is the biodegradable mass of carbon in the waste,

$C_{W R_{B Z T_{5}}} \quad-$ is the mass of biodegradable carbon introduced into the reactor with recirculated leachate,

$C_{U S_{B T_{5}}} \quad-$ is the mass of biodegradable carbon removed with the leachate from the reactor,

and

$$
\begin{aligned}
C_{W P R_{B Z T_{5}}} & =\sum_{j=1}^{r} Ł_{R_{B Z T_{5}}}\left(t_{j-1}, t_{j}\right] \frac{M_{C}}{M_{O_{2}}} \\
C_{U S_{B Z T_{5}}} & =\sum_{j=1}^{r} Ł_{B Z T_{5}}\left(t_{j-1}, t_{j}\right] \frac{M_{C}}{M_{O_{2}}}
\end{aligned}
$$

where:

$C_{B I O_{R}} \quad-$ is the total load of BOD removed in the leachate,

$C_{B I O} \quad-$ is the total BOD load in the leachate recirculation,

$C_{W P R_{B Z T_{5}}} \quad$ is the molar mass of oxygen,

$C_{U S_{B Z T_{5}}} \quad-$ is the molar mass of carbon. 


\section{RESULT AND DISCUSSION}

The properties and morphological composition of the municipal solid waste samples and stabilised waste are presented in Table 1.

Table 1. Properties and morphological composition of MSW and BSW

\begin{tabular}{|l|c|c|}
\hline \multirow{2}{*}{ Specification } & \multicolumn{2}{c|}{ Waste type } \\
\cline { 2 - 3 } & MSW & BSW \\
\hline Moisture, \% properties \\
Loss on ignition, \% of dry matter & 40.2 & 34.5 \\
Total organic carbon, kg/kg of dry matter & 58.5 & 52.2 \\
Biodegradable carbon, kg/kg of dry matter & 0.38 & 0.27 \\
\hline \multicolumn{2}{|c|}{ Morphological composition } \\
\hline Kitchen and garden waste + 10-20 mm fraction & 0.10 & 0.057 \\
Paper and cardboard & 42.5 & 32.6 \\
Glass & 17.5 & 14.9 \\
Plastics & 9.8 & 12.5 \\
Textiles & 13.5 & 17.7 \\
Multi-material packaging & 2.5 & 2.9 \\
Wood & 2.5 & 3.6 \\
Metals & 0.1 & 0.1 \\
Mineral waste, including <10 mm fraction & 1.6 & 1.9 \\
Total & 10.0 & 13.8 \\
\hline
\end{tabular}

The Municipal Solid Waste was characterised by a greater content of moisture and organic carbon than a stabilised waste. The TOC content in the aerobically treated waste was lower by $29 \%$ and the biodegradable carbon by $59 \%$.

The mass of untreated and aerobically treated waste stabilized in anaerobic reactors with recirculation (determined on the basis of the equations (2.2), (2.3) and (2.4)) were $0.12 \mathrm{~kg} / \mathrm{kg}$, and $0.064 \mathrm{~kg} / \mathrm{kg}$, respectively.

Dominant constituents of the biologically untreated wastes were kitchen and garden remains $(42.5 \%)$ as well as paper and cardboard (17.5\%). The percentages of these portions in the MSW, compared to the BSW, were higher by $23.3 \%$ and $14.8 \%$, respectively. The percentages of the other constituents in the MSW were lower than the same ones in the BSW; e.g. glass by $27.5 \%$, plastics by $31.0 \%$, textiles by $16.0 \%$, multi-material packaging by $44.0 \%$, metals by $18.7 \%$, and fine fractions below $10 \mathrm{~mm}$ by $38.0 \%$.

Table 2 shows the rate and the production of methane from untreated and aerobically treated waste stabilized with and without recirculation of leachate. 
Methane production in reactors with recirculation (SR and PR) were by $24 \%$ and $28 \%$ higher respectively than in reactors without recirculation ( $\mathrm{S}$ and $\mathrm{P}$ ). The rates of methane production were the highest in the reactor SR and the lowest in the reactor $\mathrm{S}$. The values of the methane production rate varied according to the relation $\mathrm{SR}>\mathrm{PR}>\mathrm{P}>\mathrm{S}$.

Table 2. The rate and production of methane from MSW and BSW from reactors with and without leachate recirculation

\begin{tabular}{|l|c|c|c|c|}
\hline Parameters & S & SR & P & PR \\
\hline Methane production, $\mathrm{dm}^{3}$ & 230 & 321 & 202 & 267 \\
\hline $\begin{array}{l}\text { The maximum rate of methane production, } \mathrm{dm}^{3} / \mathrm{kg} \\
\text { s.m. } \mathrm{d}\end{array}$ & 0.17 & 0.43 & 0.19 & 0.34 \\
\hline
\end{tabular}

Amounts of the methane production for each reactor were determined on the basis of daily measurements of the quantity and quality of biogas performed once per day over the 52 weeks of the study. Methane production rates shown in the table are determined by the maximum daily methane production during the period of study.

Information about biodegradability allows us to assess the pollution potential of wastes during its landfilling and a degradation efficiency of techniques used in the MBT. The fast transformation of waste into methane indicates its high biodegradability and intense running of the degradation processes. This results in a rapid exhaustion of the pollution potential of wastes. The degrees of conversion of the biodegradable waste carbon into methane in reactors $\mathrm{S}, \mathrm{SR}, \mathrm{P}$ and PR were determined on the basis of equation (1.1). The results indicate that the degree of conversion of the biodegradable carbon into methane was the highest in reactor $\mathrm{PR}$ and the lowest in reactor SR (table 3). Values of $\mathrm{W}_{\mathrm{CH} 4}$ index varied according to the relation $\mathrm{PR}>\mathrm{P}>\mathrm{SR}>\mathrm{S}$.

Table 3. Degree of transformation of biodegradable carbon contained in the waste into methane

\begin{tabular}{|c|c|c|c|c|}
\hline Reactor & S & SR & P & PR \\
\hline $\mathrm{W}_{\mathrm{CH} 4} \%$ & 10.9 & 12.5 & 16.6 & 19.7 \\
\hline
\end{tabular}

Conversion of organic carbon in the methane in the reactor of aerobically treated waste stabilized with recilculation was about $45 \%$ higher than in the reactor of untreated waste stabilized without recirculation. Despite the high production of methane in reactor SR compared to the reactor PR (20\% higher), the rate of conversion of the available carbon in the waste into methane was about $36 \%$ lower. The lower value of the $\mathrm{W}_{\mathrm{CH} 4}$ index in reactor $\mathrm{SR}$ demonstrates inhibition of the methane phase in this reactor. It happens because 
the acidic phase runs more intensely and readily available organic waste for microbial methane participates less as compared with reactor PR.

It is confirmed by the data available in literature indicating that the aerobic pretreatment of waste reduces duration of the acid phase and provides production of VFA which is beneficial for methanogenesis, in particular acetates and butyrates $[10,15]$. Presence of valeric and propionic acids in the untreated waste leads to a reduction of methane production, because it inhibits growth of certain microorganisms responsible for methanogenesis [10]. The main sources of carbon used by methane microorganisms are cellulose and hemicellulose which are classified as materials difficult to degrade under anaerobic conditions. Aerobic processing of these complex organic substances prior to anaerobic decomposition leads to the degradation of these complex organic components to make them easily available for methane-producing microorganisms $[2,10,14,19,15]$.

Research has shown that 5 weeks aerobic pre-treatment of waste by eliminating the acid phase, accelerates the emergence of stable methanogenesis condition in reactors (high rates of $\mathrm{W}_{\mathrm{CH} 4}$ ), and that leachate recirculation intensifies degradation of pre-treated waste $[11,20,16]$.

\section{CONCLUSION}

1. Preareation proved to be more significant and it has more pronounced effect than recirculation.

2. Fast transformation of waste into methane indicates high biodegradability of waste and intensely running processes of degradation.

3. Research has shown that 5 week aerobic pre-treatment of waste by eliminating the acid phase accelerates the emergence of stable methanogenesis in reactors (high rates of $\mathrm{W}_{\mathrm{CH} 4}$ ), and that leachate recirculation intensifies degradation of waste

4. Conversion of organic carbon in the methane in the reactor with aerobically treated waste stabilized with recirculation was about $45 \%$ higher than in the reactor with untreated waste stabilized without recirculation.

\section{REFERENCES}

1. Zhang Y., Yue D., Nie Y.: Greenhouse gas emissions from two-stage landfilling of municipal solid waste, Atmospheric Environment, 55, (2012) 139-143. 
2. Charles W., Walker L., Cord-Ruwisch R.: Effect of Pre-aeration and Inoculum on the Start-up of Batch Thermophilic Anaerobic Digestion of Municipal Solid Waste, Bioresource Technology 100, 8 (2009) 2329-35.

3. Council Directive 1999/31/EC of 26 April 1999 on the landfill of waste.

4. De Gioannis, G., Muntoni, A., Cappai, G., Milia, S.: Landfill gas generation after mechanical biological treatment of municipal solid waste. Estimation of gas generation rate constants, Waste Management 29, 3 (2009) 10261034.

5. Di Maria F., Sordi A., Micale C.: Experimental and life cycle assessment analysis of gas emission from mechanically-biologically pretreated waste in a landfill with energy recovery, Waste Management, 33, (2013) 2557-2567.

6. Fricke K., Santen H., Bidlingmaier W.: Biotechnological process for solving waste management problems in less economical developed countries, [in:] The Eigth International Waste Management and Landfill Symposium, Sardinia, (2001)181-194.

7. Lesteur M., Bellon-Maurel V., Gonzalez C., Latrille E., Roger J.M., Junqua G., Steyer J.P.: Alternative methods for determining anaerobic biodegradability: A review, Process Biochemistry 45 (2010) 431-440.

8. Griffith M., Trois C.: Long-term emissions from mechanically biologically treated waste: Influence on leachate quality, Water SA, 32, 3 (2006) 307314.

9. Lornage R., Redon E., Lagier T., Hebe I., Carre J.: Performance of low cost MBT prior to landfilling: Study of the biological treatment of size reduced MSW without mechanical sorting, Waste Management, 27, 12 (2007) 17551764.

10. Mshandete A., M., Björnsson L., Kivaisi A.,K., Rubindamayugi M., S., T., Mattiasson B.: Effect of aerobic pre-treatment on production of hydrolases and volatile fatty acids during anaerobicdigestion of solid sisal leaf decortications residues, African Journal of Biochemistry Research, 2, 5 (2008)111-119.

11. Morris J.W.F., Vasuki N.C., Baker J.A., Pendleton C.H.: Findings from long-term monitoring studies at MSW facilities with leachate recirculation, Waste Management, 23, 7 (2003) 653-666.

12. Myszograj S.: Study on susceptibility of domestic sewage to biodegradation under laboratory conditions, Chemical Industry, 87, 5 (2008) 527-530.

13. Robinson H.D., K. Knox, B.D. Bone.: Improved definition of leachate source term from landfills Phase 1: review of data from European landfills, Science Report Environment Agency September 2004. 
14. Rich Ch., Gronow J., Voulvoulis N.: The potential for aeration of $M S W$ landfills to accelerate completion, Waste Management, 28, 6 (2004) 10391048.

15. Salati S., Scagliaa B., Di Gregorio A., Carrera A., Adani F.: Mechanical biological treatment of organic fraction of MSW affected dissolved organic matter evolution in simulated landfill, Bioresource Technology 143, (2013) 131-138.

16. Sanphoti N., Towprayoon S., Chaiprasert P., Nopharatana A.: The effects of leachate recirculation with supplemental water addition on methane production and waste decomposition in a simulated landfill, Journal of Environmental Management, 81, 1 (2006), 27-35.

17. Scaglia B., Salati S., Di Gregorio A., Carrera A., Tambone A., Adani F.: Short mechanical biological treatment of municipal solid waste allows landfill impact reduction saving waste energy content, Bioresource Technology 143, (2013) 131-138.

18. Stegman R., Christensen T.H., Cossu R.: Landfilling of waste:biogas, London, New Your, NY:E\&FN Spon 1996 ISBN 0419194002.

19. Suna Erses A., Onay T., Yenigun O.: Comparision of aerobic and anaerobic degradation of municipal solid waste in bioreactor landfills, Bioresource Technology 99, 13 (2008) 5418-5426.

20. Sponza D.T., Ağdă O.N.: Impact of leachate recirculation and recirculation volume on stabilization of municipal solid wastes in simulated anaerobic bioreactors, Process Biochemistry, 39, 12 (2004) 2157-2165.

21. Visvanathan C., Mechanical biological pre-treatment of solid waste prior to landfill, International Symposium MBT 2005.

22. Woldeyohans A.,M., Worku T., Kloos H., Mulat W.: Treatment of leachate by recirculating through dumped solid waste in a sanitary landfill in Addis Ababa, Ethiopia, Ecological Engineering, 73, (2014) 254-259.

23. Sun Y., Sun X., Zhao Y.: Comparison of semi-aerobic and anaerobic degradation of refuse with recirculation after leachate treatment by aged refuse bioreactor, Waste Management, 31, 6 (2011) 1202-1209.

\section{OCEAN PODATNOŚCI NA ROZKŁAD BIOLOGICZNY ODPADÓW PRZED I PO TLENOWYM PRZETWORZENIU}

\section{Abstract}

Decydujący wpływ na ilość i czas trwania emisji zanieczyszczen ze składowisk ma udział materii organicznej w odpadach. Dyrektywa Rady Unii Europejskiej 1999/31/WE 
nałożyła na Polskę i inne kraje członkowskie obowiązek zmniejszenia ilości łatwo ulegających biodegradacji odpadów organicznych kierowanych na składowiska. W krajach rozwijających się, zalecaną metodą biologicznej stabilizacji odpadów przed składowaniem jest rozkład tlenowy. Istotną zaletą stosowania biostabilizacji odpadów w warunkach tlenowych jest intensyfikacja rozkładu organicznych frakcji odpadów do postaci łatwoprzyswajalnej dla mikroorganizmów prowadzących beztlenowy rozkład odpadów na składowisku. W artykule przedstawiono wpływ tlenowego przetwarzania odpadów i recyrkulacji odcieków na podatnośc odpadów na rozkład biologiczny odpadow stabilizowanych $\mathrm{w}$ beztlenowych reaktorach laboratoryjnych. Badania wykazały, że konwersja węgla organicznego w metanu w reaktorze odpadow po tlenowym przetworzeniu z recyrkulacją, była o około $45 \%$ wyższa, niż w reaktorze nieprzetworzonych odpadów stabilizowany bez recyrkulacji.

Słowa kluczowe: wstępne tlenowe przetworzenie odpadów, produkcja biogazu, odpady komunalne, podatności na rozkład biologiczny odpadów

Editor received the manuscript: 11.03.2014 